\title{
Spiral-horned antelopes of the Early Pleistocene Tamanian faunal complex of Eastern Europe
}

\begin{abstract}
Innessa A. Vislobokova \& Vadim V. Titov*
ABSTRACT. The current evidence confirms the presence of only one species of spiral-horned antelopes, Pontoceros ambiguus, in the Tamanian (late Early Pleistocene) faunal complex of Eastern Europe. The re-study of fossil materials revealed that the horn core from the Tsimbal locality (Sennaya) on the Taman Peninsula (Russia), previously identified as Tragelaphus sp., belongs to an antelope of this species.

How to cite this article: Vislobokova I.A., Titov V.V. 2020. Spiral-horned antelopes of the Early Pleistocene Tamanian faunal complex of Eastern Europe // Russian J. Theriol. Vol.19. No.1. P.37-44. doi: 10.15298/ rusjtheriol.19.1.03.
\end{abstract}

KEY WORDS: Pontoceros ambiguus, Tamanian complex, late Early Pleistocene, Eastern Europe.

Innessa A.Vislobokova [ivisl@paleo.ru], Borissiak Paleontological Institute of the Russian Academy of Sciences, 123 Profsoyuznaya, Moscow 117667, Russia; Vadim V.Titov [vvtitov@yandex.ru], Southern Scientific Center of the Russian Academy of Sciences, Rostov-on-Don 344006, Russia.

\section{О винторогих антилопах раннеплейстоценового таманского фаунистического комплекса Восточной Европы}

\begin{abstract}
И.А. Вислобокова, В.В. Титов*
РЕЗЮМЕ. Имеющиеся на сегодня данные позволяют говорить о присутствии в таманском (конец раннего плейстоцена) фаунистическом комплексе Восточной Европы лишь одного вида винторогих антилоп, Pontoceros ambiguus. Ревизия ископаемых материалов показала, что роговой стержень из местонахождения Цимбал (Сенная) на Таманском полуострове (Россия), ранее определенный как Tragelaphus sp., также принадлежит антилопе этого вида.
\end{abstract}

КЛЮЧЕВЫЕ СЛОВА: Pontoceros ambiguus, таманский комплекс, ранний плейстоцен, Восточная Европа.

\section{Introduction}

The Tamanian faunal complex was first introduced by Gromov (1948) as one of the biochronological units of East European Pleistocene based on large mammals. Its type locality is Sinyaya Balka on the Taman Peninsula (Russia); another characteristic locality known at that time in the same region was Tsimbal sand pit (near Sennaya Village, currently Sennoi) (Gromov, 1948; Vereshchagin, 1957, 1959). Later, a number of new mammal localities of this complex have been discovered on the Taman Peninsula and north-eastern Sea of Azov coastal area in Russia, and also in Azerbaijan and Georgia (e.g. Dubrovo, 1963; Alekseeva, 1977; Vangengeim et al., 1991; Baigusheva, 2000; Tesakov, 2004; Dodonov et al., 2006; Tesakov et al., 2007, 2013; Baigusheva \& Titov, 2008; Bukhsianidze et al., 2014). The index fossil of the Tamanian complex is Archidiskodon meridionalis tamanensis Dubrovo, 1964. The most characteristic

\footnotetext{
* Corresponding author
}

species include Equus aff. suessenbornensis Wüst, 1901, Stephanorhinus etruscus (Falconer, 1868), and Elasmotherium caucasicum Borissiak, 1914 (Gromov, 1948; Vereshchagin, 1957; Dubrovo \& Alekseev, 1964; Alekseeva, 1977; and others). Based on biostratigraphic and paleomagnetic data, the time range of the Tamanian (s.str.) complex was estimated as ca. 1.2-0.865 Ma, from MIS 36 to the MIS 22/MIS 21 boundary, approximately in the interval between the Cobb Mountain paleomagnetic Subchron and the Brunhes/Matuyama Chron boundary (Vangengeim et al., 2001; Vislobokova \& Tesakov, 2013; Markova \& Vislobokova, 2016; and others). At least four small-mammal assemblages (Nogaiskian, Kairian, Morozovian, and Petropavlian) correspond to the Tamanian complex (Markova, 2007). According to another biochronological scheme, the Tamanian (s.1.) complex may include three East European regional small-mammal zones (MQR9, MQR8, and MQR7B), and its duration may be longer, with the lower age limit around 1.5 Ma, MIS 52 (Tesakov, 2004; Tesakov et al., 2007); 1.55 Ma: Titov et al., 2012; Tesakov et al., 2017). 
In Western Europe, the analogues of this assemblage are the faunas of the late Early Pleistocene, late Late Villafranchian - Early Galerian, or Epivillafranchian, large-mammal zone MNQ20 and a part of MNQ21(e.g. Kahlke et al., 2011; Nomade et al., 2014; Palombo, 2018). It corresponds to the Pirro Faunal unit of Italy (Petronio et al., 2011).

Currently, Sinyaya Balka (Bogatyri), with its stone artifacts, is one of the oldest Paleolithic sites in Europe (Shchelinsky et al., 2010), and the study of the faunas of the Tamanian complex is of particular interest in connection with the reconstruction of the ancient human settlement and environment at the end of the Early Pleistocene. These tasks require the revision of the faunal list of large mammals of the Tamanian complex, especially the composition of herbivores, in particular bovids, as possible resource species for the Paleolithic humans.

Two species of spiral-horned antelopes, Tragelaphus sp. and Pontoceros ambiguus, are listed for the Tamanian faunal complex in a number of well-known publications (e.g., Fundamentals of Paleontology, 1962; Catalog of Mammals of the USSR, 1981). The main purpose of this article is to revise the list of spiral-horned antelopes of the Tamanian complex based on the re-study of horn cores from Tsimbal and Nogaisk stored in the Paleontological Institute of the Russian Academy of Sciences (Moscow), fossil materials from Eastern Europe, and published data.

We present here a new description of the horn core of a spiral-horned antelope from the Tsimbal locality and its comparison with materials of Pontoceros ambiguus from the south of Eastern Europe. The new data clarifies the diagnosis of $P$. ambiguus. Moreover, the study provides new evidence on morphology and evolution of this species.

\section{Background}

The first finds of spiral-horned antelopes of the Tamanian complex have been made in Tsimbal on the Taman Peninsula (Vereshchagin, 1957; Alekseeva, 1977). The fauna of Tsimbal is referred to the small-mammal zone MQR8, the latest in the Tamanian complex (Tesakov, 2004; Kurshakov et al., 2016). The incomplete horn core from the Late Pliocene (= Early Pleistocene in modern stratigraphical divisions) of Tsimbal, the Krasnodar Museum-Reserve KM 2479 P-176, was originally described as Tragelaphus sp. from a locality near Krasnodar(Sokolov, 1955). Sokolov (1955) pointed to the difficulty in determining its position (the right or left half of the skull) because of the peculiarities of the specimen (only a small part of the frontal bone is preserved). Nevertheless, he suggested that the specimen could be a left horn core with a heteronymous twisting typical for recent species of Tragelaphus widely distributed in Africa. The same specimen KM 2479 and distal part of the metatarsal were also described as Tragelaphus sp. by Vereshchagin (1957) together with the finds from Tsimbal sand pit.

Later, a new spiral-horned antelope Pontoceros ambiguus has been discovered in the Lower Pleistocene of southern Eastern Europe and the Caucasus. This antelope was a member of the Psekupsian, Tamanian, and Tiraspolian faunal complexes. In addition to the holotype from the Nogaisk locality in Ukraine, the species description was based on the horn cores from the Margaritovo 2 locality (late Early Pleistocene, MNQ20/MNQ21) in Russia and Tiraspol (Kolkotova Balka; early Middle Pleistocene, MNQ22) in Moldova (Vereshchagin et al., 1971). The holotype of P. ambiguus has been apparently recovered from the lower layers of the Nogaisk section, i.e. below the layer with the
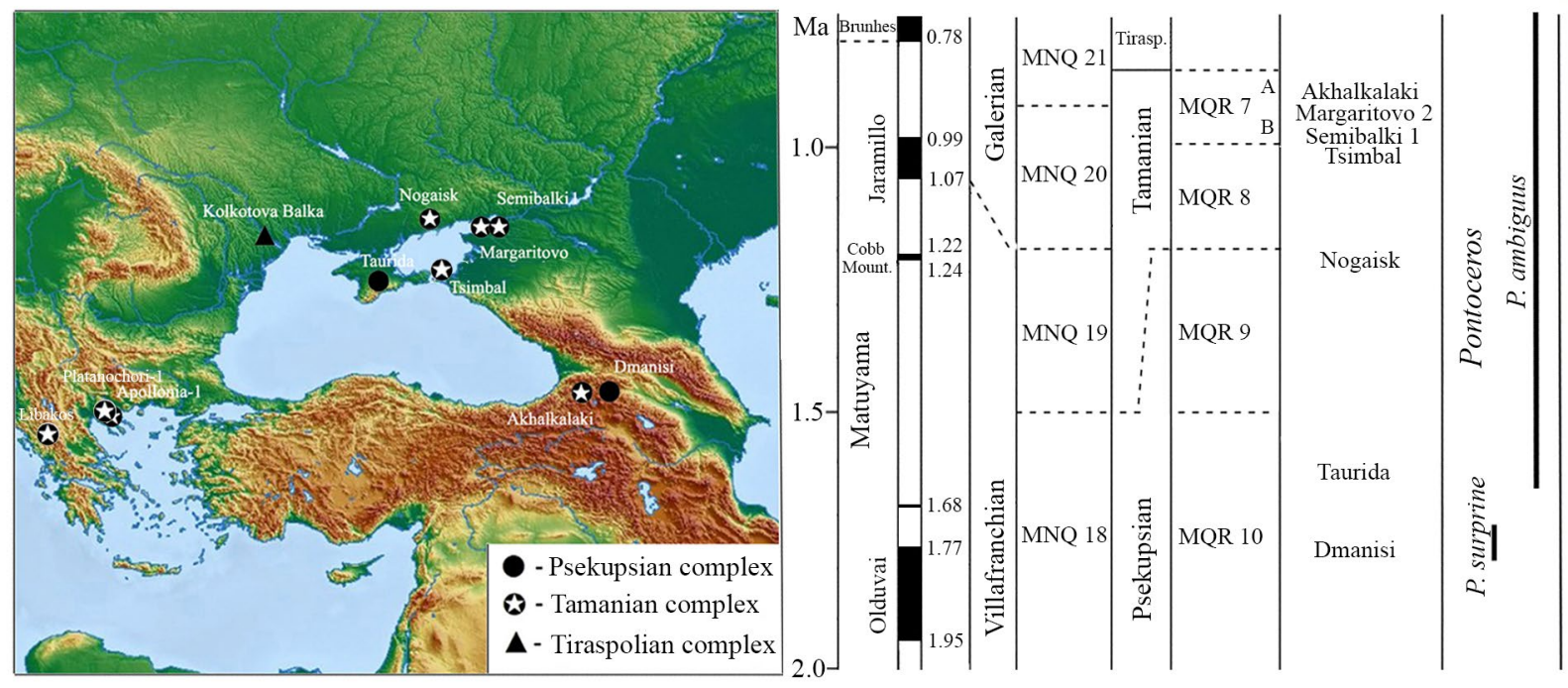

Fig. 1. Geographic distribution of main finds of Pontoceros, chronological position of East European and Caucasian localities, and chronological range of species. 
Nogaiskian small-mammal fauna, and has been attributed by Vereshchagin et al. (1971) to the Khaprovian (s.1.) complex. Its late phase suggested by Alekseeva (1977) approximately corresponds to the Psekupsian complex and may include a part of the Tamanian (s.1.) complex, with its lower boundary at $1.5 \mathrm{Ma}$.

In contrast to Tragelaphus, Pontoceros is characterized by homonymously (clockwise) torsioned horn cores. Fossil remains of Pontoceros are also found at Libakos (1.8-1.2 Ma, MNQ19), Apollonia 1 (ca. $1 \mathrm{Ma}, \mathrm{MNQ}$ 20) and Platanochori-1 (latest Villafranchian) in Greece (Kostopoulos, 1997; Koufos \& Kostopoulos, 1997; Konidais et al., 2015), Dmanisi (ca. 1.8 Ma, MNQ18) and Akhalkalaki (0.98-0.78 Ma, MNQ20) in Georgia (Vekua, 2012; Bukhsianidze et al., 2014), and Taurida Cave (1.8-1.5 Ma, MNQ18) on the Crimean Peninsula (Lopatin et al., 2019; Vislobokova et al., 2020) (Fig. 1). As a member of the Tamanian complex, $P$. cf. ambiguus was recorded at the Semibalki 1 locality (MNQ20, MQR7) in the northeastern Sea of Azov coastal area in Russia (Baigusheva et al., 2016).

The first discovery of $P$. ambiguus has cast doubt on the validity of the previous identifications of antelope specimens from the Taman Peninsula as Tragelaphus and raised the question of whether they could belong to Pontoceros (Vereshchagin et al., 1971). However, the issue remained unresolved, and both, Tragelaphus and Pontoceros were formally regarded as two members of the Early Pleistocene faunas of Eastern Europe (e.g. Alekseeva, 1977; Catalog of Mammals of the USSR, 1981).

The present re-study of the horn core of "Tragelaphus sp." from Tsimbal and its comparison with the holotype of $P$. antiquus along with a revision of data on the morphology of representatives of Pontoceros and other spiral-horned antelopes from the Lower Pleistocene of Eastern Europe and the Caucasus confirm the suggestion of Vereshchagin et al. (1971).

\section{Systematic paleontology}

Order Artiodactyla Owen, 1848

Family Bovidae Gray, 1821

Genus Pontoceros Vereschagin, Alexejeva, David et Baigusheva, 1971

Pontoceros ambiguus Vereschagin, Alexejeva, David et Baigusheva, 1971

Figs. 2-3, Table 1

Tragelaphus sp.: Sokolov, 1955, p. 217-219; Vereshchagin, 1957, p. 60-61; Fundamentals of Paleontology 1962, p. 398; Alekseeva, 1977, p. 139; Catalog of Mammals of the USSR, 1981, p. 386.

Pontoceros ambiguus: Vereshchagin et al., 1971, p. 167-169, figs. 61 and 62, table XXXIV, figs. 1 and 2; Alekseeva, 1977, p. 139-141, fig. 27; Kostopoulos, 1997, p. 866-873, figs. 14 and 15; Lopatin et al., 2019, p. 42; Vislobokova et al., 2020, p. 81, 84-88, fig. 3.

Pontoceros cf. ambiguus: Baigusheva et al., 2016, p. 30 .
Holotype (Fig. 2A). Geological Institute, Russian Academy of Sciences, Moscow, GIN 938-1, a right horn core with a part of the cranial roof; Nogaisk, northern coast of the Sea of Azov, Ukraine; Lower Pleistocene.

Diagnosis (after Vereshchagin et al., 1971). Medium-sized antelope with elongated, almost straight horn cores, which are homonymously twisted (torsioned), bearing three keels, and having a triangular cross-section.

Emended diagnosis (after Kostopoulos, 1997 with additions). Medium sized antelope with almost straight, homonymously torsioned horn cores, situated above the orbits and almost in the plane of the forehead. The frontals are slightly convex between the bases of horn cores, and the supraorbital foramens are large. The horn cores are strongly inclined backwards, at an angle of about $30-40^{\circ}$ to the parietal part of the cranial roof; in their proximal part, they are parallel to each other or slightly divergent. At about half their length, the horn cores slightly bend backwards and outwards. They have three well developed keels. Numerous fine longitudinal grooves cover the surface of the horn cores, and the furrows associated with the keels are also present. The cross-section of the horn cores is rounded-triangular from the base almost up to the top. In the anterolateral face of the horn base, there are three well developed foramens of various size. The frontoparietal suture is Y-shaped. The teeth are meso-hypsodont. The limb bones are elongated and slender.

Material. Incomplete right horn core with a part of the frontal, Krasnodar State Historical and Archeological Museum-Reserve, KM 2479 P-176; Tsimbal, the Taman Peninsula; upper Lower Pleistocene; a lower half of a right horn core with a part of the frontal bone, Rostov Regional Museum, ROMK 142; Margaritovo 2; incomplete left horn core with a part of the frontal bone, Azov MuseumReserve, AMZ KP 28320/19, Semibalki 1; north-eastern coast of the Sea of Azov; upper Lower Pleistocene.

Description and comparison. The specimen KM 2479 P-176 from Tsimbal is a right horn core broken off at about half the horn core length, approximately at the level where the horn core slightly bents backwards (Fig. 2B). The horn morphology and the structure of the preserved surface of the brain cavity correspond well to those of the holotype of P. ambiguus from Nogaisk. The horn core was located above the orbit and it is homonymously torsioned. There are three well-developed keels, i.e. anteromedial, anterolateral, and posteromedial according to their proximal insertion (their descending points). All the keels are similar in structure to those in the holotype but less sharp; probably, due to the poor preservation of the specimen (possible smoothening due to abrasion). The anteromedial and anterolateral keels are well-developed and more sharpened than the posteromedial keel. Sokolov (1955), who first described this specimen, noted a slight development of the posteromedial (posterolateral in its first description) keel, flattening upwards. According to our data, the anteromedial keel is smoothed only at the base and sharpened up to the distal end of the specimen similarly to that in the holotype. The anterolateral keel is the strongest one and more sharply projected as in the holotype. At its base, there are one large and two 


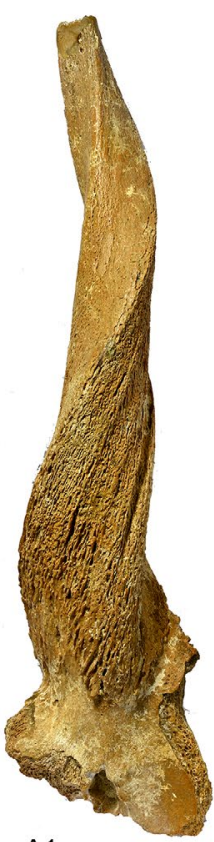

A1

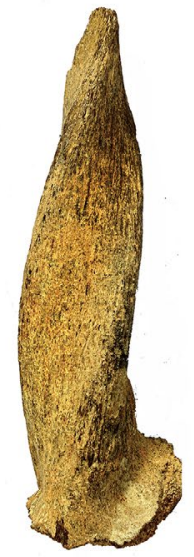

B1

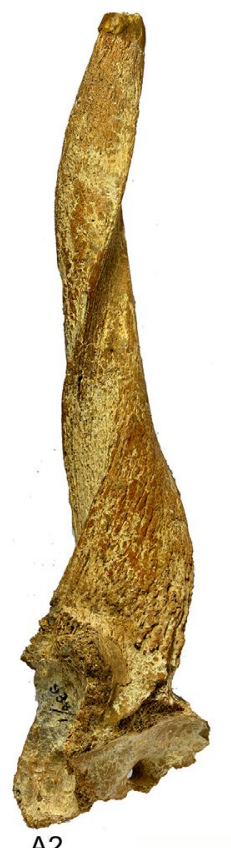

A2

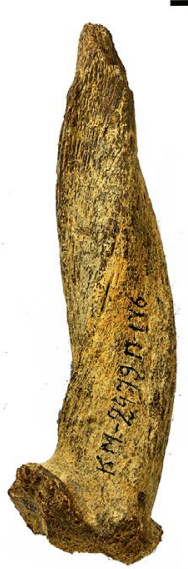

B2
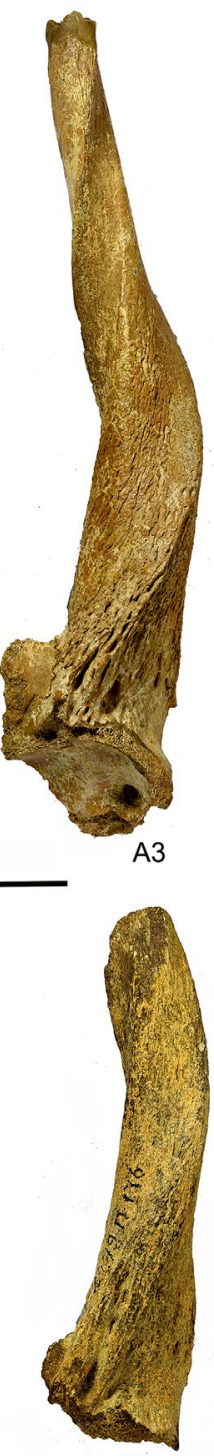

B3
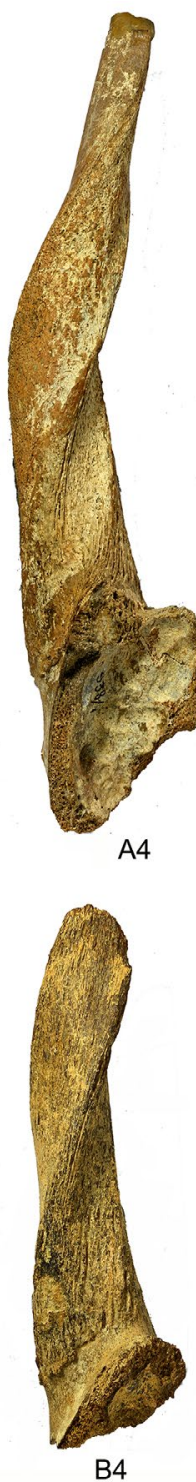

B4

Fig. 2. Pontoceros ambiguus: A - holotype, GIN 938-1, right horn core with a part of the cranial roof: anterior (A1), posterior (A2), lateral (A3), and medial (A4) views; Nogaisk, Ukraine; Lower Pleistocene; B — KM 2479 P-176, incomplete right horn core with a part of the frontal: anterior (B1), posterior (B2), lateral (B3), and medial (B4) views; Tsimbal, Russia; Lower Pleistocene. Scale equals $5 \mathrm{~cm}$.

smaller vascular foramens. The large vascular foramen is associated with a distinct furrow which is about $40 \mathrm{~mm}$ in length in KM $2479 \mathrm{P}-176$ and about $45 \mathrm{~mm}$ in the holotype. Unlike the holotype and $P$. ambiguus from the Taurida Cave, the posterormedial keel in KM 2479 P-176 starts at some distance from the frontoparietal suture. In the holotype and in the antelope from the Taurida Cave, the descending point of the posterormedial keel is located very close to the frontoparietal suture. In the holotype, this keel is sharply pointed and slightly bents anteriorly at their insertion point and then flattened upwards. In difference from the holotype which demonstrates almost parallel horn cores in their proximal part, the horn core from Tsimbal suggests a slight divergence. In KM 2479 $\mathrm{P}-176$, the furrow, associating the anteromedial keel, is very poorly traced; in the holotype, the same furrow starts $40 \mathrm{~mm}$ above the base and disappears $125 \mathrm{~mm}$ from the base. The horn core in KM 2479 P-176 is twisted in approximately one coil (turn) from the base to its distal end, and, therefore, the torsion of a complete horn core (from the base to the tip) could be close to 1.25 coils as in the holotype. Numerous fine longitudinal grooves run across the horn core surface. The cross-section of the horn core is rounded-triangular at the base and along the whole specimen length. The transversal diameter of the horn core base slightly exceeds its anteroposterior diameter as in the holotype (Table 1).

The specimen from Margaritovo 2 ROMK 142 represents the proximal half of a right horn core, with a typical $P$. ambiguus features and three well-marked keels 

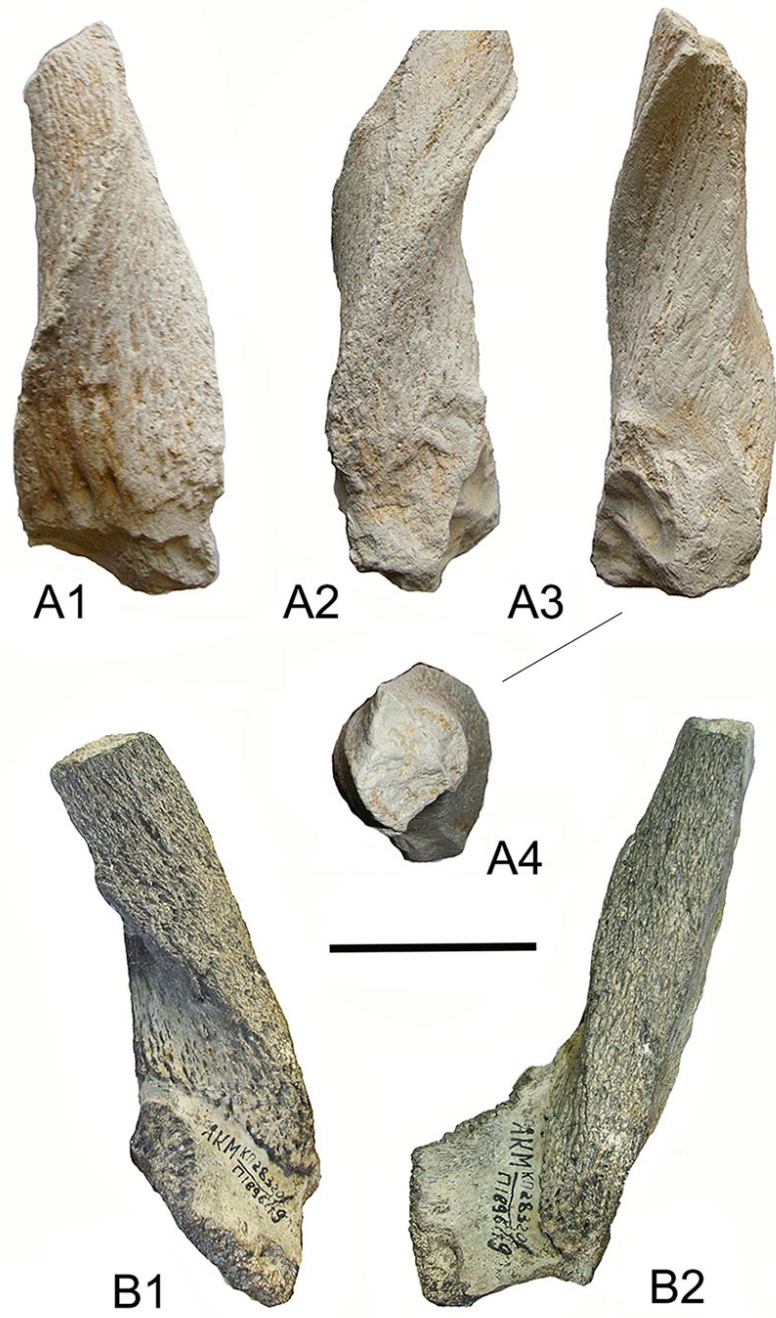

Fig. 3. Pontoceros ambiguus: ROMK 142, A — incomplete right horn core with a part of the frontal: anterior (A1), posterior (A2), lateral (A3), and medial (A4) views, cast; Margaritovo 2, Russia; Lower Pleistocene; B - AMZ KP 28320/19, incomplete left horn core with a part of the frontal: medial (B1) and anterior (B2) views; Semibalki 1, Russia; Lower Pleistocene. Scale equals $5 \mathrm{~cm}$.

which are homonymously twisted (Fig. 3A). All the keels are sharpened to the distal end of the specimen (Fig. 3A).

The specimen from Semibalki 1 AMZ KP 28320/19 represents the left frontal broken off (abrupt) along a "Y-shaped" frontoparital and interfrontal sutures and the proximal part of the horn core split along its longitudinal axis (Fig. 3B). The frontals are slightly convex between the horn bases as in the holotype. The horn core is directed backwards, and lies almost in the plane of forehead. The inner side of its proximal part is not parallel to the interfrontal suture; therefore, the horn cores were slightly divergent as in the antelope from Tsimbal. The pedicle is not observable, the horn core is homonymosly torsioned, and the anteromedial keel is very strong and sharp. The distance between the horn bases could be slightly less than twice the anteroposterior diameter of the horn core's base.
In its dimensions, the specimen from Tsimbal is smaller than the holotype, whereas the specimens from Margaritovo 2 and Semibalki 1 approximately correspond in size to the holotype. Measurements of horn cores and indexes are given in Table 1.

All three specimens differ from horn cores in P. surprine Vekua, 2012 from Dmanisi by their smaller size and stronger inclination backwards, the presence of three keels, and a triangular cross-section.

\section{Discussion and conclusions}

The type of horn core torsion (twisting) is one of the main characters used for identification of the genera of spiral-horned antelopes. The homonymous type of horn core torsion in Pontoceros distinguishes 
Table 1. Horn cores of Pontoceros ambiguus from the late Early Pleistocene of Eastern Europe (L, length of the horn core; DAP, anteroposterior diameter; DT, transversal diameter; WALF, width of anterolateral face; WPF, width of posterior face; WMF, width of medial face; measurements improved by authors are marked with an asterisk; estimated complete horn length is given in square brackets ; + - approximate measurement, exceeding the mentioned one). GIN, Geological institute of Russian Academy of Sciences), Moscow; ROMK, Rostov Regional Museum of Local History, Rostov-on-Don; OPS,

Department of Paleontology and Stratigraphy of Academy of Sciences of Moldova (Institute of Zoology, Academy of Sciences of the Republic of Moldova), Kishinev, Moldova; KM, Krasnodar Regional Museum, Krasnodar, Russia; AMZ KP, Azov Museum-Reserve, Azov.

\begin{tabular}{|c|c|c|c|c|c|c|c|}
\hline \multirow{3}{*}{$\begin{array}{l}\text { Measurements } \\
(\mathrm{mm}) \\
\text { and indexes } \\
(\%)\end{array}$} & $\begin{array}{c}\text { Nogaisk } \\
\text { GIN 938/1 }\end{array}$ & $\begin{array}{c}\text { Margaritovo } 2 \\
\text { ROMK } 142\end{array}$ & $\begin{array}{c}\text { Tiraspol } \\
\text { OPS } 1259\end{array}$ & $\begin{array}{l}\text { Taurida } \\
\text { Cave }\end{array}$ & $\begin{array}{c}\text { Tsimbal } \\
\text { KM } 2479 \\
\text { P-176 } \\
\end{array}$ & \begin{tabular}{|c|} 
Semibalki 1 \\
AMZ KP \\
$28320 / 19$ \\
\end{tabular} & Apollonia 1 \\
\hline & \multirow{2}{*}{\multicolumn{3}{|c|}{$\begin{array}{l}\text { Vereshchagin et al., 1971; } \\
\text { Alekseeva, } 1977 \\
\text { min-max }\end{array}$}} & $\begin{array}{l}\text { Vislobokova } \\
\text { et al., } 2000\end{array}$ & $\begin{array}{l}\text { Sokolov, 1955; } \\
\text { Vereshchagin } \\
\text { et al., } 1971 \\
\end{array}$ & & $\begin{array}{c}\text { Kostopoulos, } \\
1997\end{array}$ \\
\hline & & & & & $\min -\max$ & & \\
\hline $\mathrm{L}$ & $246^{*} ; 250$ & - & - & - & $\begin{array}{c}167+* \\
{\left[\sim 220^{*}\right]}\end{array}$ & - & $175+-225$ \\
\hline DAP base & 46 & 46 & 42 & 46 & $42 *$ & - & $38.1-41.3$ \\
\hline DT base & 49 & 53 & 46 & 48 & $43+*$ & $52 *$ & $42.2-44.6$ \\
\hline WALF base & 50 & 54 & - & - & $45 ; 46^{*}$ & - & - \\
\hline WPF base & 40 & 46 & - & - & $33 ; 37 *$ & - & - \\
\hline WMF base & 38 & 40 & 38 & - & $37 ; 38^{*}$ & - & - \\
\hline DTbase/L & $20 *$ & - & - & - & - & - & 20 \\
\hline Number of turns & 1.25 & - & - & 1.25 & 1 or 0.75 & - & 1 \\
\hline
\end{tabular}

this genus from other Early Pleistocene spiral-horned antelopes, including Tragelaphus, Gazellospira, and Spirocerus. The presence of the genus Tragelaphus in the Early Pleistocene of Eurasia was assumed only on the basis of finds from the Taman Peninsula described by Sokolov (1955) and Vereshchagin $(1957,1959)$. The results of the present revision show that the horn core previously identified as Tragelaphus sp. belongs in fact to Pontoceros ambiguus. Comparison of the horn core from Tsimbal with fossil and recent materials revealed that this is the right horn core. Its morphology, homonymous type of torsion, rounded-triangular shape of horn core crosssection and posterior inclination correspond to those of $P$. ambiguus. Thus, at present, the Tamanian faunal complex contains only one species of spiral-horned antelopes, namely Pontoceros ambiguus.

The geographical range of $P$. ambiguus extended from the north-eastern coasts of the Sea of Azov to the south-eastern Europe and Transcaucasia and coincided with the main dispersal routes of mammals and hominins into southern Europe via the peri-Pontic area. The most ancient finds of $P$. ambiguus are known from the Taurida Cave (1.8-1.5 Ma) in the Crimea (Lopatin et al., 2019; Vislobokova et al., 2020) and Nogaisk $(>1.2 \mathrm{Ma})$ in Ukraine (Vereshchagin et al., 1971) and the youngest from Tiraspol / Kolkotova Balka $(<0.781 \mathrm{Ma})$ in Moldova (Vereshchagin et al., 1971). The latter is attributed to the beginning of the Brunhes paleomagnetic Chron and correlated with MIS 17 (Dodonov et al., 2006; Markova, 2007). In Eastern Europe, the finds of $P$. ambiguus of the Tamanian (s.str.) complex (1.2$0.8 \mathrm{Ma}$ ) are recorded in the Sea of Azov coastal area (Margaritovo 2, Tsimbal, and Semibalki 1) (Tesakov et al., 2007; Baigusheva et al., 2016, and others) (Fig. 1). In the Balkans, $P$. ambiguus is known from the faunas of Libakos of the Late Villafranchian age (1.8-1.2 Ma) and Apollonia 1 referred to the Epivillafranchian (1.2$0.8 \mathrm{Ma}$ ) (Kostopoulos, 1997; Koufos \& Kostopoulos, 2016, 2017).

The study of P. ambiguus of the Tamanian complex of Eastern Europe allowed the tracing of similarities and differences between the populations that populated eastern and western parts of its geographical range and some possible evolutionary trends.

According to Kostopoulos (1997), the population of $P$. ambiguus mediterraneus from Apollonia 1 in Greece differed from the type species from Nogaisk in the following characters: (1) less elongated horn cores; (2) more massive horn-cores (index DTbase/L is $20 \mathrm{vs}$ 16-18 for the typical P. ambiguus); (3) smoother keels; (4) weaker torsion (a complete gyre (turn) instead of more than one complete turn in the typical P. ambiguus); (5) less triangular, more elliptical-rounded cross-section; (6) foramen pattern associated with the anterolateral keel: one large and two secondary foramens; (7) not parallel (more divergent) proximal parts of horn cores, and (8) less clear or not traced contact between the horn core and the pedicle. According to our data, two of these points should be improved. The holotype from Nogaisk displays the same massiveness of the horn core (DTbase/L index equal to 20) and the similar pattern of the foramens associated with the anterolateral keel as those in P. ambiguus from Apollonia 1. However, other characters are valid for the subspecies $P$. ambiguus mediterraneus that inhabited the Balkans at the end of the Early Pleistocene. 


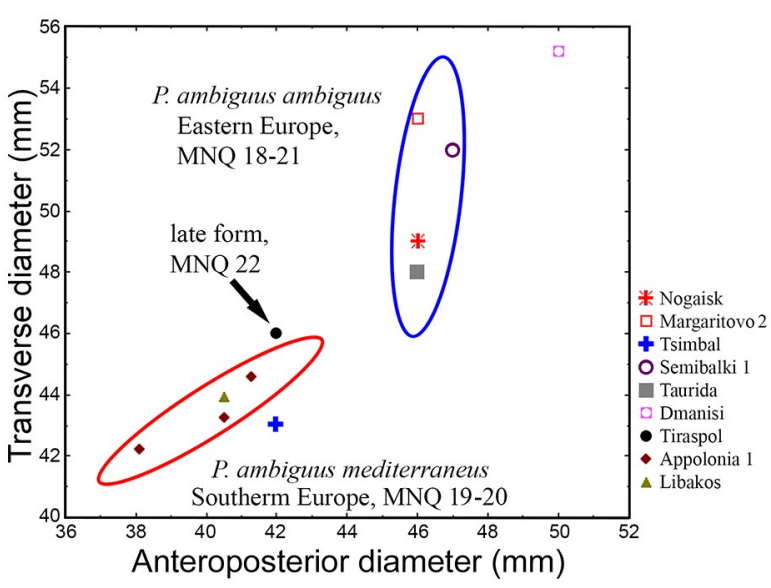

Fig. 4. Scatter diagram of anteroposterior versus transverse diameters of the horn base in Pontoceros ambiguus from different Early and Middle Pleistocene localities of Europe.

Pontoceros ambiguus from the Tamanian complex of Eastern Europe, especially its representatives associated with its regional small-mammal zone MQR7 (Semibalki 1) and MQR8 (Tsimbal) shows some similarity with $P$. ambiguus from Apollonia 1 (Fig. 4). They all are more advanced than the forms from Nogaisk and Taurida Cave in divergent proximal parts of horn cores and less pronounced contact between the horn core and the pedicle. In addition, $P$. ambiguus from Tsimbal and Apollonia 1 share smaller horn core size and smoother keels than those in the antelopes from Nogaisk and Taurida Cave.

The similarity of antelopes, that inhabited the Taman and Balkan Peninsulas in the time interval of $1.2-0.8 \mathrm{Ma}$ and their difference from earlier forms may reflect the same evolutionary trends or close relationships. Clarification of these questions requires more fossils and further research.

ACKNOWLEDGEMENTS. We thank the employees of the Azov Historical, Archeological and Paleontological Museum-Reserve and Rostov Regional Museum, Geological Institute of the Russian Academy of Sciences for the opportunity to study their collections. The authors are very grateful to Prof. Dimitris Kostopoulos and Dr. Maia Bukhsianidze for the review of this article and for their very useful comments. This work was fulfilled in the framework of the Russian State program of Southern Scientific Centre RAS, project No.01201363186 and was partly supported by the Basic Research Program of the Presidium of the Russian Academy of Sciences "The Evolution of the Organic World: The Role and Influence of Planetary Processes".

\section{References}

Alekseeva L.I. 1977. [Early Anthropogene Theriofauna of Eastern Europe]. Nauka: Moscow. 216 p. [in Russian].
Baigusheva V.S. 2000. [New data on the Tamanian faunistic complex from the excavation near the Semibalki Village (the Sea of Azov coast)] // [Historical and Archeological Research in Azov and Lower Don in 1998]. Azov: Azov Historical, Archeological and Paleontological MuseumReserve. No.16. P.27-57 [in Russian].

Baigusheva V.S. \& Titov V.V. 2008. The Taman Faunistic complex of large vertebrates of the Azov and Lower Don regions // Early Paleolithic of Eurasia: New Discoveries. Abstracts of the International Conference (Krasnodar, Temryuk, 1-6.09.2008). Rostov-on-Don: Southern Scientific Centre RAS. P.123-124.

Baigusheva V.S., Titov V.V., Tesakov A.S. \& Timonina G.I. 2016. [Theriofauna of the locality Semibalki 1 in the northeastern Sea of Azov coast (Tamanian faunal complex, Eopleistocene)] // Theriofauna of Russia and Adjacent Territories. Moscow: KMK Scientific Press. P.30 [in Russian].

Bukhsianidze M. 2005. The fossil Bovidae of Dmanisi. Doctoral Thesis. Ferrara: University of Ferrara. 192 p.

Bukhsianidze M., Chagelishvili R., Hertler C., Kvavadze E. \& Martkoplishvili I. 2014. New findings about the Akhalkalaki site (Southern Georgia, Caucasus; 0.98-0.78 Ma) // Kostopoulos D.S., Vlachos E. \& Tsoukala E. (eds). Abstracts of 6th International Conference on Mammoths and Their Relatives. Thessaloniki: Scientific Annals, School of Geology, Aristotle University. Vol.102. P.38.

[Catalog of Mammals of the USSR (Pliocene-the present)]. Gromov I.M. \& Baranova G.I. (eds). 1981. Moscow: Nauka. 456 p. [in Russian].

Dodonov A.E., Zhou L.P., Markova A.K., Tchepalyga A.L., Trubikhin V.M., Aleksandrovski A.L. \& Simakova A.N. 2006. Middle-Upper Pleistocene bio-climatic and magnetic records of the Northern Black Sea coastal area // Quaternary International. Vol.149. P.44-54.

Dubrovo I.A. 1963. [New evidence on the Tamanian faunal complex of vertebrates] // Bulletin of the Moscow Society of Naturalists. Geological Series. Vol.38. No.6. P.94-99 [in Russian].

Dubrovo I.A. \& Alekseev M.N. 1964. [To the stratigraphy of the Quaternary sediments of the Sea of Azov] // Bulletin of the Commission for Study of the Quaternary. No.29. P.35-43 [in Russian].

[Fundamentals of Paleontology. Mammals]. 1962. Orlov Yu.A. (ed.). Moscow: State Scientific and Technical Publishing House of Literature on Geology and Nedra Protection. 421 p. [in Russian].

Gromov V.I. 1948. [Paleontological and Archeological foundation of the Quaternary Stratigraphy of Continental Sediments in the USSR] // Transactions of the Geological Institute of the Academy of Sciences of the USSR, Series Geology. Vol.64. No.17. 521 p. [in Russian].

Kahlke R.-D., García N., Kostopoulos D.S., Lacombat F., Lister A. M., Mazza P.A., Spassov N. \& Titov V.V. 2011. Western Palaearctic palaeoenvironmental conditions during the Early and early Middle Pleistocene inferred from large mammal communities, and implications for hominin dispersal in Europe // Quaternary Science Reviews. Vol.30. P.1368-1395.

Konidaris G.E., Tourloukis V., Kostopoulos D.S., Thompson N., Giusti D., Michailidis D., Koufos G.D. \& Harvati K. 2015. 
Two new vertebrate localities from the Early Pleistocene of Mygdonia Basin (Macedonia, Greece): preliminary results // Comptes Rendus Palevol. No.14. P.353-362.

Kostopoulos D.S. 1997. The Plio-Pleistocene artiodactyls (Vertebrata, Mammalia) of Macedonia 1. The fossiliferous site "Apollonia-1", Mygdonia basin of Greece // Geodiversitas. Vol.19. No.4. P.845-875.

Koufos G.D. \& Kostopoulos D.S. 2016. The Plio-Pleistocene large mammal record of Greece: Implications for early human dispersals into Europe // Paleoanthropology of the Balkans and Anatolia: Human Evolution and its Context. Dordrecht, the Netherlands: Springer. P.269-280.

Koufos G.D. \& Kostopoulos D.S. 1997. Biochronology and succession of the Plio-Pleistocene macromammalian localities of Greece // Aguilar J.P., Legendre J. \& Micheaux J. (eds). Mem. Trav. E.P.H.E. Actes du Congres BIOCHROM 97, Inst. Montpellier. No.21. P.619-634.

Kurshakov S.V., Frolov P.D. \& Tesakov A.S. 2016. [Materials to fauna of early Eopleistocene locality Nesmeyanovka (Martynovskiy District, Rostov Region] // Zelenkov N.V \& Parkhaev P.Yu. (eds.). [Modern Paleontology: Classic and Latest Methods. Abstracts of 13 All-Russian Scientific School of Young Paleontologists]. Moscow: Paleontological Institute RAS. P.17-18.

Lopatin A.V., Vislobokova I.A., Lavrov A.V., Startsev D.B., Gimranov D.O., Zelenkov N.V., Maschenko E.N., Sotnikova M.V., Tarasenko K.K. \& Titov V.V. 2019. Taurida cave, a new locality of the Early Pleistocene vertebrates in Crimea // Doklady Biological Sciences. Vol.485. P.40-43.

Markova A.K. 2007. Pleistocene mammal faunas of Eastern Europe // Quaternary International Vol.60. No.1. P.100-111.

Markova A.K. \& Vislobokova I.A. 2016. Mammal faunas in Europe at the end of the Early - beginning of the Middle Pleistocene // Quaternary International. Vol.420. P.363-377.

Nomade S., Pastre J., Guillou H., Faure M., Guérin C., Delson E., Debard E., Voinche P. \& Message E. 2014. 40Ar/39Ar constraints on some French landmark Late Pliocene to Early Pleistocene large mammalian paleofaunas: Paleoenvironmental and paleoecological implications // Quaternary Geochronology. Vol.21. P.2-15.

Palombo M.R. 2018. Faunal dynamics in SW Europe during the late Early Pleistocene: Palaeobiogeographical insights and biochronological issues // Comptes Rendus Palevol. Vol.17. P.247-261.

Petronio C., Bellucci L., Martiinetto E., Pandolfi L. \& Salari L. 2011. Biochronology and palaeoenvironmental changes from the Middle Pliocene to the Late Pleistocene in Central Italy // Geodiversitas. Vol.33. No.3. P.485-517.

Shchelinsky V.E., Dodonov A.E., Baigusheva V.S., Kulakov S.A., Simakova A.N., Tesakov A.S. \& Titov V.V. 2010. Early Palaeolithic sites on the Taman Peninsula (Southern Azov Sea region, Russia): Bogatyri/Sinyaya Balka and Rodniki // Quaternary International. Vol.223-224. P.28-35.

Sokolov I.I. 1955. [New species of antelopes of the Tertiary fauna from the south of the USSR] // Transactions of the Zoological Institute of the Academy of Sciences of the USSR. Vol.17. P.217-223 [in Russian].

Tesakov A.S. 2004. [Biostratigraphy of Middle PlioceneEopleistocene of Eastern Europe (based on small mammals)]. Moscow: Nauka. 248 p. [in Russian].
Tesakov A.S., Dodonov A.E., Titov V.V. \& Trubikhin V.M. 2007. Plio-Pleistocene geological record and small mammal faunas, eastern shore of the Azov Sea, Southern European Russia // Quaternary International. Vol.160. P.57-69.

Tesakov A.S., Titov V.V., Baygusheva V.S., Velichko A.A., Timireva S.N., Simakova A.N., Borisova O.K., Morozova T.D., Semenov V.V., Syromyatnikova E.V., Shishkov V.A., Kononov Y.M., Konstantinov E.A., Kurbanov R.N., Kurshakov S.V. \& Frolov P.D. 2013. VIII All-Russian Conference on Quaternary Research: Basic Problems of Quaternary, Research Results, and the Main Trends of Future Studies. Field Excursions Guidebook (Rostov-on-Don, Russia, 10-15 June 2013). Rostov-onDon: SSC RAS Publishing. 48 p. [in Russian].

Tesakov A.S., Titov V.V., Sotnikova M.V., Bondarev A.A., Simakova A.N. \& Frolov A.A. 2017. [Revised Quaternary biochronological scheme of Eastern Europe and Western Asia] // Basic Problems of Quaternary: Research Results, and the Main Trends of Future Studies. Moscow: GEOS. P.422-424 [in Russian].

Titov V.V., Tesakov A.S. \& Baigusheva V.S. 2012. [To the question of the volume of the Psekupsian and Tamanian faunistic complexes (Early Pleistocene, south of Eastern Europe)] // [Paleontology and Stratigraphic Boundaries. 58th Session of the Paleontological Society. Saint Petersburg: VSEGEI. P.142-144 [in Russian].

Vangengeim E.A., Pevzner M.A. \& Tesakov A.S. 2001. Zonal subdivisions of the Quaternary in Eastern Europe based on small mammals // Stratigraphy. Geological Correlation. Vol.3. P.280-292.

Vangengeim E.A., Vekua M.L., Zhegallo V.I., Pevzner M.A., Taktakishvili I.G. \& Tesakov A.S. 1991. [Position of the Tamanian Faunal complex in the stratigraphic and magnitochronological scales] // Bulletin of the Commission for Study of the Quaternary. Vol.60. P.41-52 [in Russian].

Vekua A. 2012. New spiral-horned antelope in Dmanisi fauna // Bulletin of the Georgian Academy of Sciences. Vol.6. No.3. P.139-144.

Vereshchagin N.K. 1957. [Remains of mammals from the Lower Quaternary deposits of the Taman Peninsula] // Transactions of the Zoological Institute of the Academy of Sciences of the USSR. Vol.22. P.9-74 [in Russian].

Vereshchagin N.K. 1959. [Mammals of the Caucasus]. Moscow-Leningrad: Academy of Sciences of the USSR. 764 p. [in Russian].

Vereshchagin N., Alekseeva L., David A. \& Baigusheva V. 1971. Genus Pontoceros // Nikiforova K. (ed.). Pleistocene of Tiraspol. Kishinev: Shtiinsa. P.167-170 [in Russian].

Vislobokova I. \& Tesakov A. 2013. Early and Middle Pleistocene of Northern Eurasia // Elias S.A. (ed.). The Encyclopedia of Quaternary Sciences. Amsterdam: Elsevier. P.605-614.

Vislobokova I.A., Titov V.V., Lavrov A.V., Gimranov D.O., Startsev D.D. \& Tarasenko K.K. 2020. Early Pleistocene spiral-horned antelopes (Artiodactyla, Bovidae) from the Taurida cave (Crimea, Russia) // Paleontological Journal. Vol.54. No.1. P.81-90. 